\title{
Assessment of roof water harvesting potential of Navsari city of Gujarat State, India by Remote sensing and Geographic information system (GIS)
}

\author{
D. K. Dwivedi* \\ Department of Agricultural Engineering, Faculty of Agriculture, Sri Sri University, Cuttack \\ (Odisha), India

\section{P. K. Shrivastava} \\ Department of Natural Resource Management, College of Forestry, Navsari Agricultural \\ University, Navsari (Gujarat), India \\ *Corresponding author. Email: dhavaldwivedi42@gmail.com
}

\section{Article Info}

https://doi.org/10.31018/

jans.v13i3.2798

Received: July 3, 2021

Revised: September 9, 2021

Accepted: September 15, 2021

\section{How to Cite}

Dwivedi, D. K. and Shrivastava, P. K. (2021). Assessment of roof water harvesting potential of Navsaricity of Gujarat State, India by Remote sensing and Geographic information system (GIS). Journal of Applied and Natural Science, 13(3), 1143 - 1150. https://doi.org/10.31018/jans.v13i3.2798

\begin{abstract}
Due to the water scarcity scenario in many parts of the Navsari city, Gujarat State in India, it is imperative to adopt cost-effective technologies that could harvest rainwater for satisfying drinking water requirements. The study was conducted with the aim of assessing the rainwater harvesting potential of Navsari city using remote sensing and Geographic Information System (GIS). The built-up areas of Navsari that could harness rainwater were identified by remote sensing and GIS. The effective built-up area contributing to rainwater harvesting was found to be $3.37 \mathrm{~km}^{2}$. The classification was carried out using "Remap" to assess the extent of the built-up area. The city was divided into equal grids and classification of each grid was implemented. The ground truth data was used for the evaluation of the built-up area. The roof water harvesting potential was estimated considering the average annual rainfall of $1621 \mathrm{~mm}$ and adopting suitable runoff coefficients. The rainwater harvesting potential of roofs for rainfall of different probabilities was estimated. For return periods of 10 years, 25 years, 50 years and 100 years, the roof water harvesting potentials were estimated to be $0.226,0.261,0.287$ and 0.312 Million Cubic Metres (MCM), respectively. The estimated average roof water harvesting potential of Navsari city was 164 million litres per year, capable of satisfying the drinking water demand of approximately 1.12 lakh people annually. The rainwater harnessed from the rooftop could augment the current water supply and immensely help in fulfilling the drinking water demand of Navsari.
\end{abstract}

Keywords: Geographic information system, Rainwater harvesting, Roof water harvesting structure, Remote sensing, Water

\section{INTRODUCTION}

India shares $17 \%$ of the world population but $4 \%$ of its geographical area and $2.5 \%$ of water resources (Black, 2016). India has nearly $33 \%$ of its geographical area in the semiarid and arid category. Further out of its total arable area, nearly $60 \%$ is rainfed without the benefits of surface water irrigation. The importance of groundwater recharge in arid and semi-arid regions is very important particularly as most of the population residing in these regions depend on groundwater for drinking and irrigation purposes. These areas are reeling under recurrent droughts chronically suffer from acute drinking water scarcity and miserable state of hygiene due to poor sanitation. With surface water in short supply, these areas are mainly dependent on groundwater which is, therefore, under severe strain (Das, 2019). Freshwater availability in several river basins of India is likely to decrease owing to climate change (Gosainet al., 2006). The paving of pervious surfaces with roads, shopping centres and driveways ultimately lead to the reduction of infiltration into the ground and increase in surface runoff. As a consequence of the incessant growth of buildings and other urban development works, the natural terrain is replaced by almost impermeable surfaces. Almost $80 \%$ of the runoff from the built surfaces flows to the waste-water disposal system or rivers and only $20 \%$ infiltrates into the soil causing ecological damage (Markoviet al., 2014) .In such scenarios, the collection and storage of rainwater to sup- 
plement existing water supply sources should be implemented. The utilization of rainwater is one of the best methods that can aid in sustainable urban development (Kim et al., 2005). The rainwater collection and its utilization to satisfy the demand for arid and semi-arid regions that cannot cope with the needs of potable water apparently seem to be the only option as rainwater in most cases is the purest water source contains very low impurities. It is necessary to adopt rainwater harvesting methods in places where the conventional water supply has failed to meet the peak period demand of the people for drinking water. Rainwater harvesting is one of the most economical and practical methods to provide supplementary water supplies for drinking purposes. Also, if the drinking water supply by the rainwater harvesting structure is sufficient, then the supplementary water can be used for domestic purposes. The only cost-effective solution to minimize the demand-supply gap by augmenting the existing water supply seems to be rainwater harvesting (Shrivastava et al., 2019).

Roof water harvesting is a process of collecting runoff occurring due to rainfall from the impermeable terrace on top of the house and conserving it in a tank (Durodoloet al., 2020). This method is comparatively easier and reliable and provides good quality water for drinking. The collected rainwater can either be used as the principal or as a supplementary source of water. Rainwater harvesting from building rooftops and parking lots could provide a source for drinking water after proper treatment (Abdulla and Alshareef, 2009). The quality of the harvested rainwater improves with roof flushing as the rainfall events progress which indicates the importance of flushing diverted used in rainwater harvesting systems (Mendez et al., 2011). The hardness of rainwater is zero, which eliminates the requirement of a sophisticated water treatment process (Jythiprakash and Sahte, 2009).

Roof water harvesting is a proven approach towards conserving water effectively and economically. Roof water harvesting should be recommended for potable water requirements in areas suffering from water scarcity after monsoon and if reliable measures are taken, water quality remains acceptable (Shrivastava et al., 2019). The roof water harvesting method has been used since ancient times for providing water for drinking during water shortage. The roof water harvesting concept varies from small and basic, such as attachment of a pipe draining into an underground tank, to large and complex, such as those to collect water from many hectares serving a large number of people. Roof water harvesting was mostly used in areas that lacked alternative water supply forms such as coral islands (Datr et al., 2006; Devi et al.,2005) and arid remote locations devoid of suitable surface or groundwater resources (Tripathi and Pandey, 2005).In India, in the year 2011, the average annual per capita water availability was estimated to be $1,545 \mathrm{~m}^{3}$. When the annual water availability per capita is less than $1700 \mathrm{~m}^{3}$, the condition falls under water-stressed category whereas annual per capita water availability below $1,000 \mathrm{~m}^{3}$ is considered as a water scarcity condition (Intended Nationally Determined Contributions Report, 2015). Ponds and pans, dams, terracing, percolation tanks, and Nala bunds are the most common types of rainwater harvesting techniques in arid and semi-arid regions (Oweis et al., 2012). The rooftop rainwater harvesting is a costeffective method and popular owing to its simplicity (lqbal et al.2015).

Lade and Oloke (2013) assessed the rainwater harvesting potential in Ibadan, Nigeria by hydrological analysis using rainfall data for 30 years from two meteorological stations, with the aim of providing a more sustainable water supply. It was found that rooftop water harvesting is technically feasible considering the current rainfall pattern, with over $90 \%$ of households having a rooftop constructed from technically appropriate materials. Results of the study indicated that an average roof of $80 \mathrm{~m}^{2}$ collected 82,835 litre/yr (45 litre/ person/day) for a family of five people, which was about the required water demand for drinking and cooking purposes. Gangulyet al. (2014) studied the prospects and possibilities of rainwater harvesting in the Shimla region of Himachal Pradesh, which experienced water shortages in summer periods due to increase in population and climatic conditions. The result of their study showed that rain water can be stored throughout the year without incurring any significant losses. It was revealed that around $30 \%$ of the water requirement could be met by the harvested rainwater. Panigrahi (2017) conducted a study aiming to develop awareness towards judicious use of water among masses and efficient ways to harvest roof top rain water resources at institutional / multi-storeyed buildings in the Malda district of West Bengal. It was reported that Malda district had a huge potential for rooftop rainwater harvesting. Mohanty et al. (2018) conducted a study of roof water harvesting structures in Marijita village of Jagatsinghpur district, Odisha. The total water demand for the selected household was about 185400 litres, out of which 5400 litres of water was used for drinking purpose considering 3 litres of water per person per day, while 180000 litres of water required for other users with 100 litres per person per day. The rooftop water harvesting system provided 148320 litres of water for the household.

Rainwater harvesting through rooftops is an appropriate method of water conservation and Indian government has mounted this as a part of watershed management programme. With the changing climate, highintensity rains with fewer rainy days or uneven distribution of rainfall both spatially and temporally result in instant flooding and runoff. Moreover, due to the re- 
moval of vegetative cover and denuding forests and concretisation, rainwater does not get sufficient time to recharge groundwater aquifers, resulting in water scarcity immediately after the monsoon. The present study was conducted to assess the roof water harvesting potential of Navsari by estimating the roof area using remote sensing and geographic information system (GIS).

\section{MATERIALS AND METHODS}

The study was conducted in Navsari city $\left(20.9467^{\circ} \mathrm{N}\right.$ and $72.9520^{\circ} \mathrm{E}$ ) situated in the Navsari district of South Gujarat was selected as the study area. It is the $9^{\text {th }}$ biggest municipal corporation of Gujarat. The city is located at an elevation of $9 \mathrm{~m}$ from the mean sea level. According to the 2011 census, the population of Navsari city was 1.71 lakh. The average annual rainfall of Navsari is $1621 \mathrm{~mm}$. The current population of Navsari city may have surpassed 2 lakh.

In this study, the roof water harvesting potential of Navsari city has been assessed using remote sensing, GIS and ground truth data. Rainfall endowment of the area is the total quantity of water obtained due to rainfall from a particular area and rainwater harvesting potential is the total rainwater amount that can be harvested effectively.

$$
V=A \times R \times C
$$

where,

$\mathrm{V}=$ Volume of water received $\left(\mathrm{m}^{3}\right)$

$A=$ Area of catchment $\left(\mathrm{m}^{2}\right)$

$\mathrm{R}=$ Rainfall depth $(\mathrm{m})$

$\mathrm{C}=$ Runoff coefficient

In order to assess the rooftop rainwater harvesting potential, it is essential to have information about the mean rainfall depth in which the rainwater harvesting system is to be adopted. The data about average rainfall can be obtained from the local weather stations. In this study, the rainfall data was provided by the Department of Agro-Meteorology of Navsari Agricultural University, located in the city of Navsari. The catchment characteristics should be analysed so that the amount of runoff generated for a given amount of rainfall can be estimated. The catchment also determines the quality of rainwater that is harvested. If contaminants are present in the catchment, then the catchment should not be used for rooftop rainwater harvesting. The runoff coefficient indicates the amount of runoff that will be generated on account of the rainfall.

The type of the catchment and the area of the catchment over which the rainfall occurs, determine the quantity of runoff. The roof catchment with tiles allows maximum runoff to the extent of about $85 \%$, whereas rooftop catchments with brick material obstructs runoff to a certain extent and generate runoff which is only up to $60 \%$ of the total rainfall occurring over the roof catchment (Pacey and Cullins, 1989). To obtain the volume of the rain water harvested, the depth of rainfall was multiplied by the catchment area. Roof foot print is the actual roof area that is used for calculating the volume of water. For plane horizontal rectangular or other shape roofs, roof foot print was same as the roof and thus effective area was same. The runoff coefficient is defined simply as the ratio of design runoff to design rainfall (Şen, and Altunkaynak, 2006). Runoff volume from 53 buildings were calculated and compared with the rainfall volume to obtain the average runoff coefficient.

The runoff volume from the building terraces was analysed corresponding to daily rainfall data. The average runoff coefficient was calculated by dividing the total runoff volume by rainfall volume. The building terraces were chosen based on the type of catchment. The average runoff coefficient was then used in the estimation of roof water harvesting potential. It was found thatthe runoff coefficient for roof varies with the type of roof, area of the roof, slope, degree of imperviousness and surface roughness. The runoff coefficients for various rooftops are provided in Table 1. More than $90 \%$ of the houses and buildings in Navsari had roof made up of tiles or concrete and the slope towards the drainage was found to be mild.

The city was divided into 35 grids of equal dimensions and "Remap software" was used for land use/land cover classification of each grid in which classes such as roads, barren land, built-up area, agriculture land, ponds etc. were differentiated. Remap uses advanced remote sensing methods and the Google Earth engine to access the satellite data directly. In order to achieve the lowest error rate and highest classification accuracy, it was ensured that the training points were sufficient in number (>20) and accurately located for each class. The error rate corresponds to the percentage of all training points incorrectly classified by the model (Murray et al., 2018).

The city has been continuously expanding due to the increasing population and increasing number of houses in the outskirts of the city. The satellite image of October 2020 was used to assess the roof area of the city. The city area of $17.5 \mathrm{~km}^{2}$ was selected as it had the

Table 1. Runoff coefficients for various rooftops (Source: Pacey and Cullins, 1989)

\begin{tabular}{ll}
\hline Type of catchment & Coefficients \\
\hline Tiles & $0.8-0.9$ \\
Corrugated metal sheets & $0.7-0.9$ \\
Concrete & $0.6-0.8$ \\
Brick pavement & $0.5-0.6$ \\
\hline
\end{tabular}


major potential for rainwater harvesting and the area of each grid was $0.5 \mathrm{~km}^{2}$. The land use classification was carried out for individual grids and they were also checked with the ground truth data by using the latitudes and longitudes of the locations. A GPS meter was used to obtain the latitudes and longitudes of various locations. The grids were assigned numbers from 1 to 35 and the software was trained separately for each grid to minimize error in land use classification. The class of interest was the built-up area which included commercial and residential buildings, bungalows and small houses with roof area for water harvesting. In addition to that, ground-truthing was also carried out to analyse the areas capable of rooftop rain water harvesting. Ground truth refers to the information that is collected from the location. The information about the roof area and the feasibility of collecting rainwater for storage was obtained through ground truth. In the parking area and the surrounding open area, there was the possibility of storing around $5 \%$ of the total runoff generated through rainfall on the roof, considering the cost and the area available. A building with $461 \mathrm{~m}^{2}$ roof area generated 597825 litres which will require a costly tank with dimensions in excess of the available area. It was feasible to construct an economic tank with $3.2 \mathrm{~m}$ length, $3.2 \mathrm{~m}$ width, and $3 \mathrm{~m}$ depth that can be cleaned easily. This tank had a storage capacity of 30720 litres, approximately $5 \%$ of the total rainwater available from the roof.

The annual rainfall at various recurrence intervals was obtained using the Weibull'sprobability plotting formula using the rainfall data of 35 years (1984-2018). The annual rainfall data was arranged in descending order and rank was assigned from lowest to highest.. The following formula was used to obtain the exceedance probability of rainfall (Raghunath, 2006).

$$
P(x \geq X)=\frac{m}{n+1}
$$

where,

$\mathrm{m}=$ Rank of the event,

$\mathrm{n}=$ Number of events

$P(x \geq X)=$ Probability of Exceedence

Recurrence interval was then obtained by taking the reciprocal of probability (Raghunath, 2006). The roof water harvesting for recurrence intervals of 2, 5, 10, 25, 50 and 100 years were then estimated using the same methodology described above.

\section{RESULTS AND DISCUSSION}

The satellite image of Navsari divided into 35 equal grids of $0.5 \mathrm{~km}^{2}$ is shown in Fig 1. An example of land use classification of Grid 10 is given in Fig. 2. The land use classification of the remaining grids is shown in Fig. 3.

The land use classification of Navsari city is presented in Table 2. In the present study, the compound area and other adjoining areas are also included in the 5.62 $\mathrm{km}^{2}$ of built-up area. The observations indicated that the roof area was approximately $60 \%$ of the built-up area and therefore, the roof area was taken as 3.37 $\mathrm{km}^{2}$.In most cases, the observed runoff from the roofwas found to be around $65 \%$ of the total rainfall and therefore, the runoff coefficient considered for concrete roof was taken as 0.60 . The variation of rainfall depth at various probabilities and the average rainfall depth for

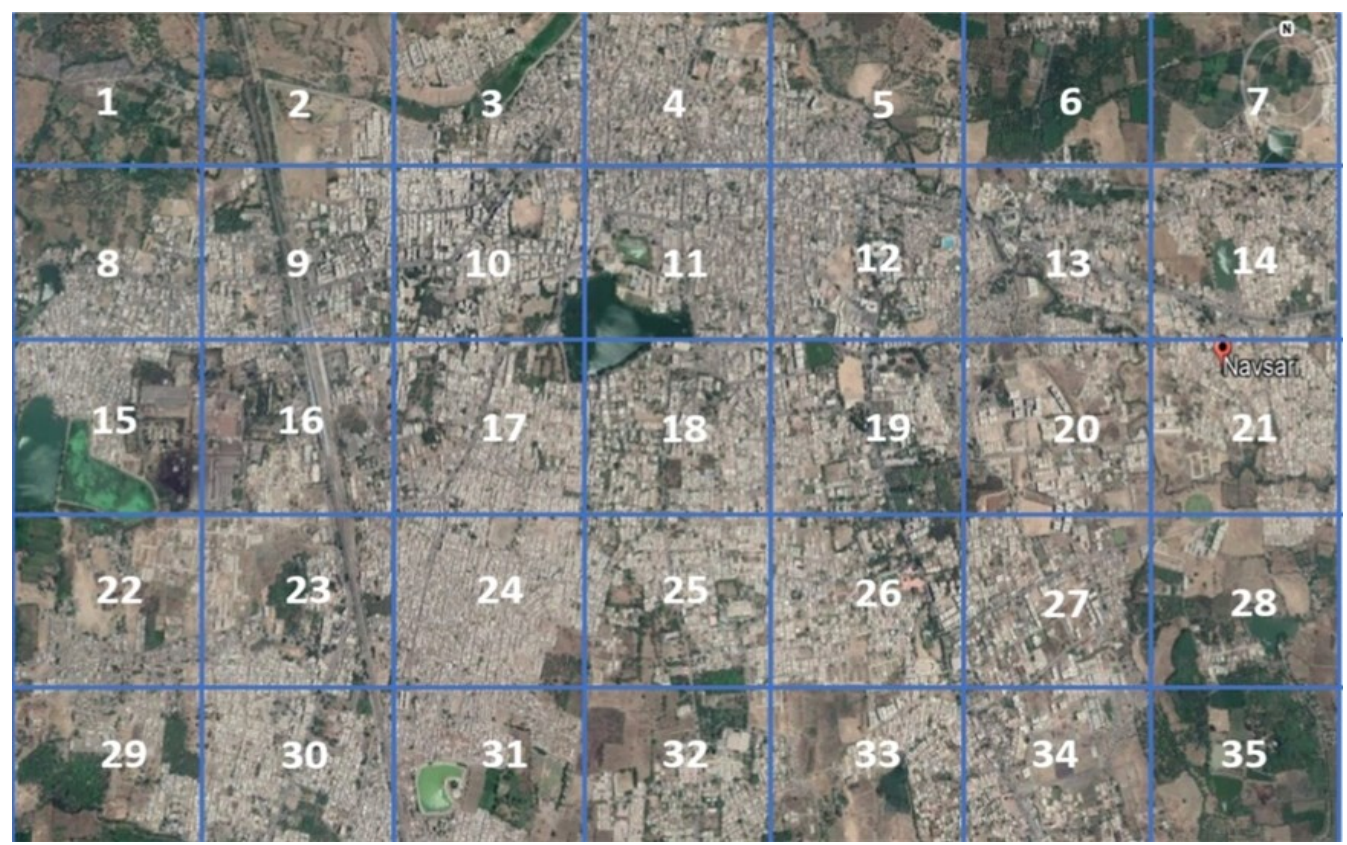

Fig. 1.Satellite image of Navsari city (27/10/2020) 
Dwivedi, D. K. and Shrivastava, P. K. / J. Appl. \& Nat. Sci. 13(3), 1143 - 1150 (2021)

\begin{tabular}{llll}
\hline \multicolumn{2}{l}{ Table 2. Land use/land cover classification of Navsari city } & \\
\hline Sr. No. & Land use / Land cover & Area $\mathbf{( k m}^{\mathbf{2}}$ & Percentage Cover \\
\hline 1 & Water bodies & 0.28 & 2 \\
2 & Barren land & 6.65 & 38 \\
3 & Roads & 1.20 & 7 \\
4 & Trees/ Agriculture & 3.75 & 21 \\
5 & Built up & 5.62 & 32 \\
& Total Area & 17.50 & 100 \\
\hline
\end{tabular}

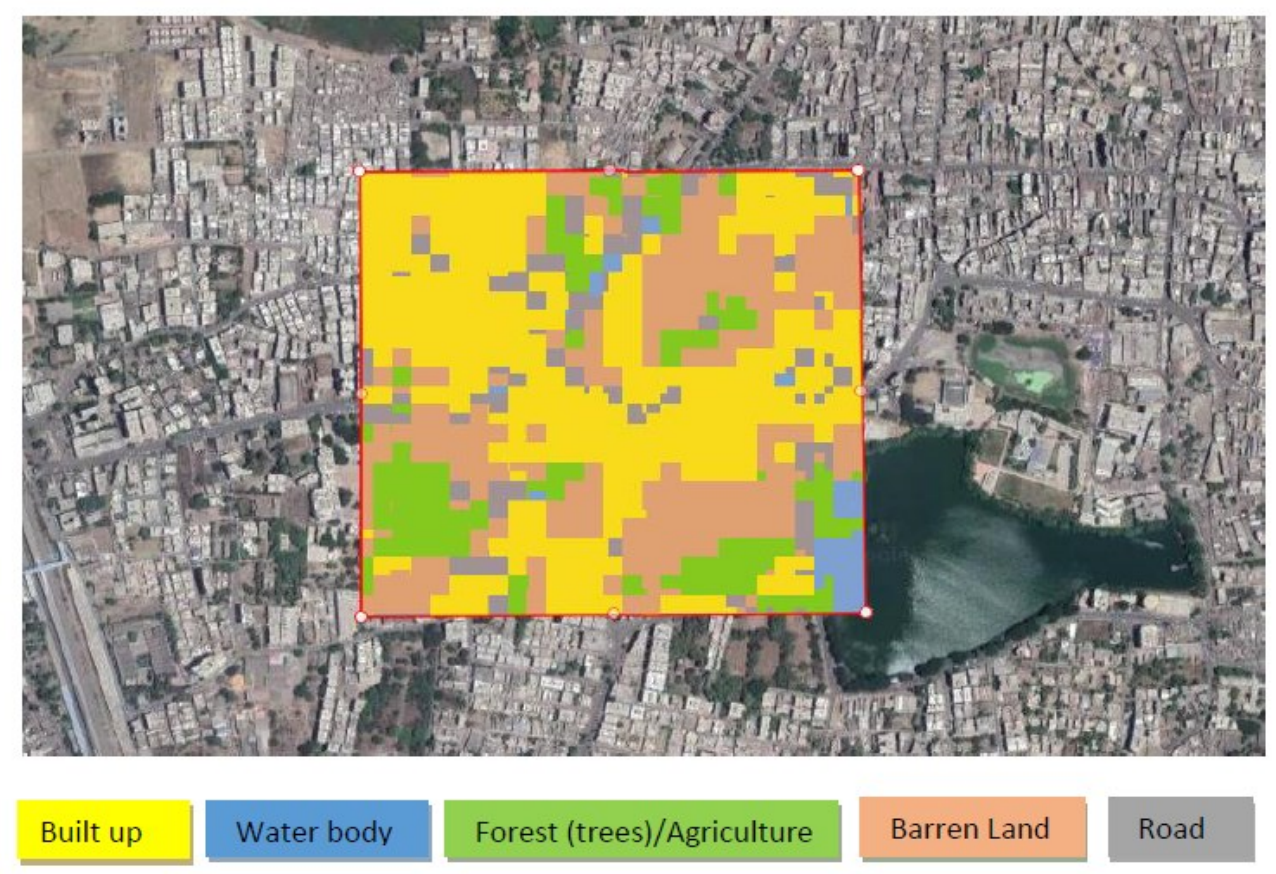

Fig. 2. Land use / land cover classification of Grid 10 of Navsari city

various recurrence intervals are shown in Fig. 4 and Fig. 5, respectively. The amount of rainwater that could be obtained from the rooftop was found to be 3280 million litres per year, considering average rainfall of 1621 $\mathrm{mm}$. However, it will not be possible to store all the available water obtained from rooftop in all the houses and buildings, as it requires provision for an underground tank in the vicinity or in the basement of the residential area. The estimated roof water harvesting potential for the average rainfall depth is given in Table 3 . The roof water harvesting potential corresponding to different rainfall depths is presented in Table 4 and Fig.6. From the ground truth data, it was observed that only $5 \%$ of the available roof water could be stored and therefore, the estimated roof water harvesting potential was found to be $0.164 \mathrm{MCM}$. The main factors that affected the available roof water were the cost of the storage tank and the area required for the storage tank.

An average person requires approximately 4 litres of drinking water per day and therefore approximately 1460 litres of drinking water per year (WHO, 2015). The estimated amount of 164 million litres for an average annual rainfall is capable of satisfying the drinking water requirements of approximately 1.12lakh people, which is around $65.6 \%$ of the total population of Navsari. The additional amount of water could be used for small scale irrigation and domestic purposes. However, if the water is to be used for drinking, reliable commercial filter of adequate capacity should be installed along the pipeline or a filter using appropriate media should be built underground before the water is stored in the tank. In case sufficient space is not available for an underground tank, the pipes carrying water from the roofs of several houses can be connected for

Table 3. Estimated roof water harvesting potential for average rainfall depth

\begin{tabular}{ll}
\hline Roof area & $\mathbf{3 . 3 7} \mathbf{~ k m}^{\mathbf{2}}$ \\
\hline Average Annual Rainfall & $1621 \mathrm{~mm}$ \\
Runoff coefficient & 0.6 \\
Available roof water & $3.28 \mathrm{MCM}$ \\
Roof water harvesting potential (5\%) & $0.164 \mathrm{MCM}$ \\
\hline
\end{tabular}




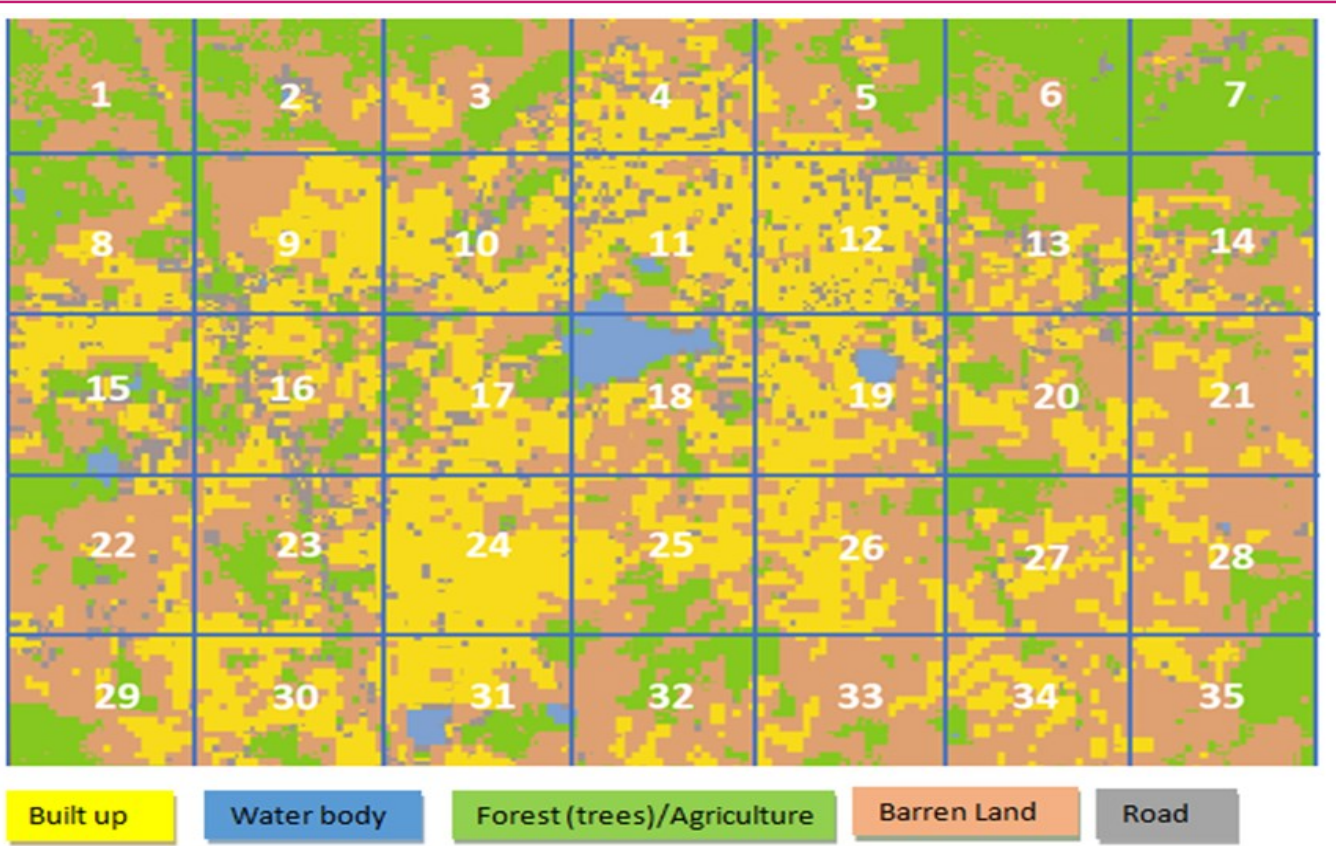

Fig. 3. Land use/Land cover classification of Navsari city (Grids: 1 to 35)

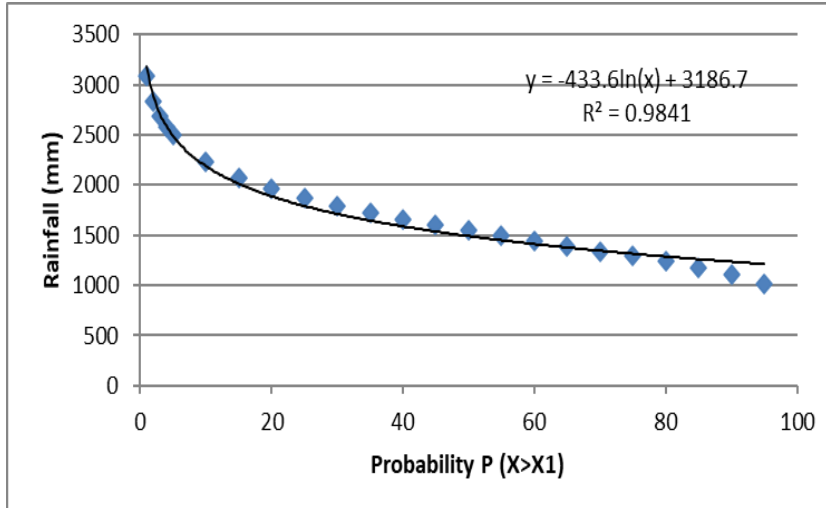

Fig. 4. Plot of annual rainfall vs. probability

diverting water to a nearby underground water tank which can be built in the barren land or common plot. If the annual rainfall is $800 \mathrm{~mm}$, which is $50 \%$ deficient than the average annual rainfall, the estimated roof water harvesting potential would be 0.162 million litres which can satisfy the drinking water requirement of 55,397 people of Navsari city, which is around $32.4 \%$ of the total population of Navsari city.

Villar-Navascuéset al. (2020) assessed the roof water harvesting potential in the city of Alicante in Spain. The results revealed that the estimated rainwater catchment potential for the whole city was $1,153,380 \mathrm{~m}^{3}$ per year for an average rainfall scenario of $293.3 \mathrm{~mm}$ and a total roof area of $5.197 \mathrm{~km}^{2}$. In the present study, the rooftop rainwater harvesting potential for an average rainfall of $1621 \mathrm{~mm}$ was estimated to be $163980 \mathrm{~m}^{3}$ per year for the total roof area of $3.72 \mathrm{~km}^{2}$. The rainwater harvesting potential was found to be considerably less than that reported by Villar-Navascuéset al.(2020)owing to the lack of sufficient area for tank construction in the

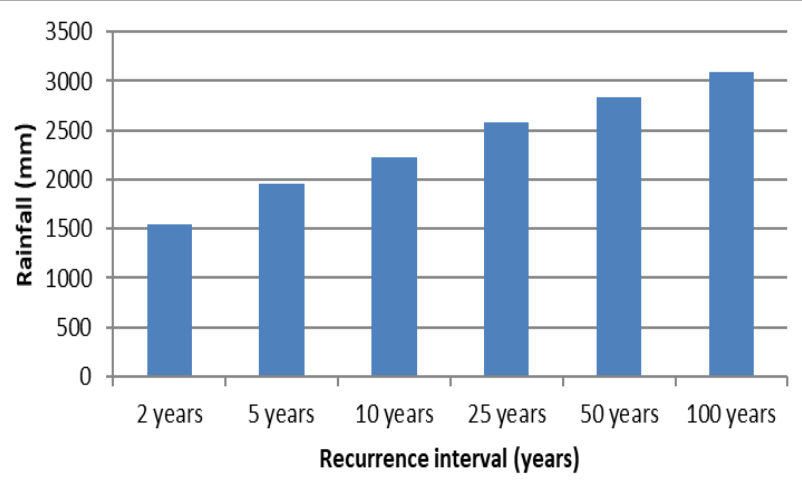

Fig. 5. Annual rainfall depth $(\mathrm{mm})$ at various recurrence intervals

densely populated city of Navsari. Dwivedi and Bhaduria (2006) had noted that the cost of rooftop rainwater harvesting system could be considerably less if it is planned before the construction of the house. A similar situation was observed in the study as most of the residential areas had not been designed considering the rooftop rainwater harvesting system. Closely spaced buildings, lack of sufficient area for the tank, lack of planning for the rainwater harvesting system, and economic constraints were some of the main problems the residents faced in adopting the rooftop rainwater harvesting system.

The rainwater harvesting potential corresponding to various rainfall depths is provided in Fig. 6 . In the last 35 years, rainfall has seldom been less than $800 \mathrm{~mm}$. The rainfall potential is based on the land use pattern of Navsari in the year 2020. For return periods of 10 years, 25 years, 50 years and 100 years, the roof water harvesting potentials were estimated to be 0.226 , $0.261,0.287$ and $0.312 \mathrm{MCM}$, respectively. Therefore, 
Table 4. Annual rainfall depth at various recurrence intervals

\begin{tabular}{lll}
\hline Return period (years) & Annual Rainfall $(\mathbf{m m})$ & $\begin{array}{l}\text { Roof water harvesting potential } \\
\text { (MCM) }\end{array}$ \\
\hline 2 & 1544 & 0.156 \\
5 & 1958 & 0.198 \\
10 & 2232 & 0.226 \\
25 & 2578 & 0.261 \\
50 & 2835 & 0.287 \\
100 & 3090 & 0.312 \\
\hline
\end{tabular}

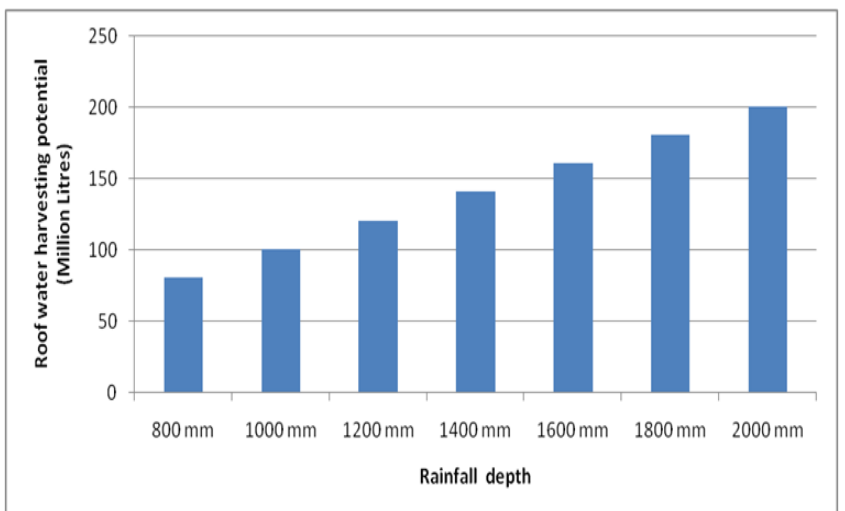

Fig. 6. Roof water harvesting potential for various rainfall depths

if sufficient provisions are made to harvest rainfall, the roof water can successfully reduce the drinking water problems of the people. However, significant investment is required to construct tanks of appropriate sizes in the house, residential buildings, schools etc. to store the required quantity of water.

\section{Conclusion}

In the present study, the estimated amount of roof water harvesting potential of Navsari city was found to be 164 million litres, capable of satisfying the drinking water requirements of approximately 1.12 lakh people. The estimated roof water harvesting potentials corresponding to a rainfall return period of 25 years and 50 years are $0.261 \mathrm{MCM}$ and $0.287 \mathrm{MCM}$, respectively. The water that can be obtained through rooftops can certainly reduce the burden on the main water supply. The city planning commission may consider the tremendous scope in harnessing rainwater to satisfy the drinking water demand of the people. The civil engineers may design the houses with sufficient space for rainwater harvesting. The estimation of roof water harvesting potential in Navsari city has not been attempted before. This study focussed on the quantity of water that can be harvested through rooftops. There is scope for detailed research on the assessment of variations in terms of the quality of harvested rainwater in various areas of the city.

\section{ACKNOWLEDGEMENTS}

The authors are thankful to the Department of Agrometeorology, Navsari Agricultural University, Navsari, for providing the data required for the research work.

\section{Conflict of interest}

The authors declare that they have no conflict of interest.

\section{REFERENCES}

1. Abdulla, F. A. \& Al-Shareef, A. W. (2009). Roof rainwater harvesting systems for household water supply in Jordan. Desalination, 243(1-3), 195-207. doi:10.1016/j.des al.2008.05.013

2. Black, M. (2016). The atlas of water: mapping the World's most critical resource. Univ of California Press.

3. Das, S. (2019). Water management in arid and semiarid areas of India. In: Ground Water Development-Issues and Sustainable Solutions (pp. 15-33). Springer, Singapore.doi:10.1007/978-981-13-1771-2_2

4. Datar, R. (2006), Designing and implementing rainwater harvesting systems for industries -case study from Mumbai, 2nd Joint International Conference on Sustainable Energy and Environment (SEE 2006), 21st - 23rd November, 2006, Bangkok, Thailand.

5. Devi, B.L., Maheshwari, B. \& Simmons, B. (2005), Rainwater harvesting for residential irrigation: how sustainable is it in an urban context, Proc. of 12 International Conference on Rainwater Catchment Systems, New Delhi, India.

6. Durodola, O. S., Bwambale, J., \&Nabunya, V. (2020). Using every drop: Rainwater harvesting for food security in Mbale, Uganda. Water Practice and Technology, 15(2), 295-310.doi:10.2166/wpt.2020.019

7. Dwivedi, A. K. \&Bhadauria, S. S. (2006). Domestic rooftop water harvesting-a case study. Ground Water, 4(6), 31-38.

8. Ganguly, R., Bansal, A., Mishra, M., and Kumar, A. (2014). Application of Rain Water Harvesting Scheme in Shimla Region. Hydrology: Current Research, 5(3), 1. doi:10.4172/2157-7587.1000180

9. Gosain, A. K., Rao, S. \& Basuray, D. (2006). Climate change impact assessment on hydrology of Indian river 
basins. Current Sci. 90(3), 346-353

10. Intended Nationally Determined Contributions Report (2015). Template for Vulnerability Assessment, Mitigation and Adaptation. Government of India. Ministry of Water Resources, River Development and Ganga Rejuvenation. National Water Mission.

11. Iqbal, K., Srivastava, A., \& Singh, S. S. (2015). Rooftop Rainwater Harvesting-Cost Effective Technique to Overcome the Overall Water Scarcity of an Area. IJSTEInternational Journal of Science Technology \& Engineering, 1(10), 182-185

12. Jothiprakash, V., \& Sathe V. (2009). Evaluation of rainwater harvesting methods and structures using analytical hierarchy process for a large scale industrial area. Journal of Water Resource and Protection, 1(6), 427-438 doi:10.4236/jwarp.2009.16052

13. Kim, R. H., Lee, S., \& Kim, J. O. (2005). Application of a metal membrane for rainwater utilization: filtration characterization and membrane fouling. Desalination, 177, 121132. doi:10.1016/j.desal.2004.12.004

14. Lade, O., and Oloke, D. (2013). Assessment of rainwater harvesting potential in Ibadan, Nigeria. Environmental Engineering Research, 18(2), 91-94.

15. Markovi, G., Zele, M., Káposztásová, D., \&Hudáková, G. (2014). Rainwater infiltration in the urban areas. WIT Transactions on Ecology and the Environment, 181, 313320.doi:10.2495/eid140271

16. Mendez, C. B., Klenzendorf, J. B., Afshar, B. R., Simmons, M. T., Barrett, M. E., Kinney, K. A., \&Kirisits, M. J. (2011). The effect of roofing material on the quality of harvested rainwater. Water Research, 45(5), 2049-2059. doi:10.1016/j.watres.2010.12.015

17. Mohanty R., Dalai A., Singh K., Das A. \& Dalai B. (2018) New approach in rainwater harvesting through rooftop water management technique: a case study. International Journal of Agriculture Sciences, 10(8), 5815-5816.

18. Murray, N. J., Keith, D. A., Simpson, D., Wilshire, J. H., \&
Lucas, R. M. (2018). Remap: An online remote sensing application for land cover classification and monitoring. Methods in Ecology and Evolution, 9(9), 20192027.doi: $10.1111 / 2041-210 x .13043$

19. Villar-Navascués, R., Pérez-Morales, A. \& Gil-Guirado, S. (2020). Assessment of Rainwater Harvesting Potential from Roof Catchments through Clustering Analysis. Water, 12(9), 2623.

20. Oweis, T. Y., Prinz, D., \&Hachum, A. Y. (2012). Rainwater harvesting for agriculture in the dry areas. CRC press.

21. Pacey, A. \& A. Cullins (1999). Rainwater harvesting. The collection of Rainfall and Runoff in the Rural areas. Technical centre for Agricultural and Rural cooperation (ACP EEC Lome Convention). 216.

22. Panigrahi (2017). Roof-Top rainwater harvesting system for official / multistoried building with reference to malda district, West Bengal. International Journal of Engineering Research and Application, 7(1), 111-115.

23. Raghunath, H. M. (2006). Hydrology: principles, analysis and design. New Age International.

24. Şen, Z., \& Altunkaynak, A. (2006). A comparative fuzzy logic approach to runoff coefficient and runoff estimation. Hydrological Processes: An International Journal, 20 (9), 1993-2009. doi:10.1002/hyp.5992

25. Shrivastava, P. K., Patel, D. P., Nayak, D., Satasiya, K. F. \& Patel, D. C. (2019). Harvesting and potable use of rooftop rain water to tackle imminent drinking water crisis in coastal Gujarat, India. Curr J Appl Sci Technol, 35(6), 110.doi:10.9734/cjast/2019/v35i630205

26. Tripathi, A. K. \& U. K. Pandey (2005). Study of rainwater harvesting potential of Zura village of Kutch District of Gujarat, Journal of Human Ecology, 18(1), 63-67. doi:10.1080/09709274.2005.11905809

27. World Health Organization (2015). WHO/UNICEF Joint Water Supply \& Sanitation Monitoring Programme. Progress on sanitation and drinking water: 2015 update and MDG assessment. World Health Organization 